\title{
Research on development strategy of "One Belt And One Road" in Jilin province
}

\author{
Dai Yundi ${ }^{1,2, a}$ Qu Li ${ }^{1, b}$ Wen Yanjiao ${ }^{1, c}$ Li Huimin $^{1, d}$ Xie Wei ${ }^{1, e}$ \\ ${ }^{1}$ Changchun university of finance and economics school of management, Changchun China 130122 \\ ${ }^{2}$ School of economics and management of Jilin agricultural university, Changchun China 130122 \\ a1013889886@qq.com, b64635835@qq.com, '1064556291@qq.com, d911961897@qq.com, ${ }^{\text {e} 9185865 @ q q . c ~}$
}

om

Keywords: Jilin province, One Belt and One Road (B\&R), countermeasures

\begin{abstract}
This paper mainly expounds the development status and advantages of "One Belt and One Road" in Jilin province. According to the current situation of Jilin province, the development opportunities of One Belt and One Road in Jilin province were analyzed. The development of "One Belt and One Road" in Jilin province was found, and the development strategy of "One Belt and One Road" in Jilin province was put forward.
\end{abstract}

\section{Development of "One Belt And One Road" in Jilin province}

Summary of the status quo. In 2013, xi's strategic vision for building "One Belt And One Road" in central Asia and Southeast Asia was a new pattern for China to optimize and open up in the new historical period. "One Belt And One Road" is short for "silk road economic belt" and "21st century maritime silk road".

"One Belt And One Road" connects the Eurasian continent to the European economic circle [1, 2].

On March 28, 2015 in Jilin province officially became associated with the "area" strategic focus of one of the provinces, the development of Jilin province to open the forerunner area as an important part of the silk road in northeast Asia, should with open eyes and conception, seize new strategic opportunity, actively seeking to the new economic growth point of the silk road available, the Jilin province with the outside world to realize effective connection, as well as exchange of needed support ability of enterprises to go out and attract more projects and funds, and then establish a benign interaction complementary advantages of big outside world. The One Belt And One Road strategy is a broad strategy for the Silk Road economic belt and the maritime silk road. We should make full use of One Belt And One Road to promote the development of regional economy in Jilin province.

Development advantages and opportunities for One Belt And One Road in Jilin province. Jilin province is located in the core area of northeast Asian economic circle, north to Heilongjiang, Liaoning province in the south, the west connected to the east of Inner Mongolia, Mongolia, north of hunching apart with the Sea of Japan are only 15 kilometers, is the only way to directly into the sea of Japan, China and Russia, the distribution in the surrounding of the many ports of the two countries. The geographical location gives Jilin province a prominent location advantage.

Jilin province occupies the superior geographical advantage, is an important hub of China's opening to the outside world, is in the east the HunChun is in the North Korea and Russia the triple junction [3]. The big four international port hunching highway port between China and Russia, sino-russian HunChun railway port, China and the DPRK river port and the china-dprk lump port, the port makes foreign import and export more convenient. The central Mongolian channel runs through the area of Jilin province and connects Mongolia to the Sea of Japan. HunChun is only 15 kilometers from the coast, and can enter the port of Japan directly through the Tumen River. The now open sea transport routes include HunChun to North Korea to South Korea, HunChun to Russia to Japan, HunChun to Russia to South Korea. 
In 2013, the railway business mileage of Jilin province reached $4222 \mathrm{~km}$ and the total mileage reached $94218 \mathrm{~km}$.During the 12th five-year plan period, the province invested 190 billion yuan to construct 25 railway projects, with total mileage of about $4180 \mathrm{~km}$.In the aspect of highway construction, the network of the whole province is perfect, and the network benefits are obvious, and the modern integrated three-dimensional transportation network system has been preliminarily formed. Meanwhile, the expressway connection between Jilin province and adjacent provinces has been fully opened, and the construction of 31 highways has been completed [3]. In aviation, construction of the construction project of feeder airports and general airports, ongoing phase ii expansion, Yanji Long Jia airport relocation project start in succession, perfected in the pattern of "one main four auxiliary" airport.

The "One Belt And One Road", the Silk Road economic belt and the 21st century maritime Silk Road, has brought opportunities to Jilin province from the "One Belt And One Road" strategy. One Belt And One Road construction should base on connectivity of border area, Jilin province as the northern Silk Road economic belt, the maritime Silk Road starting point at the northern end of the 21st century, in the new period our country opening to the outside world has great development potential. During 2010-2014, the quantity and turnover of goods in Jilin province were shown in table 1.

Table 1 the quantity and turnover of goods in Jilin province

\begin{tabular}{|c|c|c|c|c|c|}
\hline Year & Transport & Total & $\begin{array}{c}\text { Railway } \\
\mathrm{s}\end{array}$ & highway & $\begin{array}{c}\text { waterwa } \\
y\end{array}$ \\
\hline \multirow[t]{2}{*}{2010} & $\begin{array}{l}\text { freight volume (Kiloton per } \\
\text { kilometer) }\end{array}$ & 301105.1 & 7422.1 & 23558.0 & 125.0 \\
\hline & turnover (Gigatons per kilometer) & 1157.8 & 589.0 & 563.6 & 1.2 \\
\hline \multirow[t]{2}{*}{2011} & $\begin{array}{l}\text { freight volume (Kiloton per } \\
\text { kilometer) }\end{array}$ & 34771.0 & 7478.0 & 27032 & 261 \\
\hline & turnover (Gigatons per kilometer) & 1281.0 & 569.69 & 709.91 & 1.4 \\
\hline \multirow[t]{2}{*}{2012} & $\begin{array}{c}\text { freight volume (Kiloton per } \\
\text { kilometer) }\end{array}$ & 40913.0 & 7674 & 33031 & 226.0 \\
\hline & turnover (Gigatons per kilometer) & 1391.35 & 585.9 & 794.74 & 1.33 \\
\hline \multirow[t]{2}{*}{2013} & $\begin{array}{c}\text { freight volume (Kiloton per } \\
\text { kilometer) }\end{array}$ & 48447.1 & 8871.1 & 39308 & 268 \\
\hline & turnover (Gigatons per kilometer) & 1581.7 & 635.4 & 945.1 & 1.2 \\
\hline \multirow[t]{2}{*}{2014} & $\begin{array}{c}\text { freight volume (Kiloton per } \\
\text { kilometer) }\end{array}$ & 55005.3 & 10068.1 & 144614.6 & 304 \\
\hline & turnover (Gigatons per kilometer) & 1728.9 & 694.5 & 1033 & 1.4 \\
\hline
\end{tabular}

In recent years, logistics and turnover in Jilin province have been on the rise, and the demand for logistics industry has been increasing.

\section{Problems in the development of "One Belt And One Road" in Jilin province}

Imperfect logistics information system. Jilin province lacks the support of the implementation of cross-border e-commerce services, such as barriers to international trade consulting services, the market consumption hotspot research services, the market research services management regulations, brand extension services, industry support services such as integrated services platform.

Shortage of logistics professionals. Jilin province has many institutions of higher learning, but lacks logistics major. The market of vocational training is more chaotic, but the logistics management and management personnel are very few phenomena, lacking many network talents. In Jilin province, logistics enterprises mainly focus on small and medium-sized enterprises. To reduce the cost of human resources, logistics staff uses non-professional or part-time staff. The lack of many network talents is one of the crucial factors that hinder China's logistics economy development.

Inadequate infrastructure. Due to the Jilin province logistics enterprises in the initial stage, the practice of logistics enterprises purchase equipment enterprises only considers ahead of old ideas, without being aware of "right" is more important than the "possession", pressure of money, caused 
the entire logistics system the present situation of the prohibitive cost of low efficiency, to make the logistics enterprises failed to achieve high efficiency. The regional cross-border e-commerce warehouse in Jilin province is fragmented, and it is difficult to form a perfect logistics system. Jilin province still USES the traditional logistics mode, the function is relatively single, cannot effectively use the electronic technology and network information to establish the logistics system and sales logistics.

Lack of systematic supply chain. Systematic supply chain is the key and core of logistics enterprise operation and development.

Most logistics enterprises in Jilin province are in the preliminary stage of development. Their logistics and systematic services are not perfect, and the correlation between each link is not strong, resulting in inferior quality of products and low service quality.

\section{Development strategy of "One Belt And One Road" in Jilin province}

Build the "Internet + logistics" system. "Internet +" is essentially a new economic form, the Internet + traditional industry, which will promote the transformation of traditional industries or give birth to new industries. The "Internet plus" promotion of logistics upgrading so-called "Internet $+"$ is to integrate the Internet into traditional industries to promote the development of traditional industries. "Internet + logistics" can take advantage of the Internet and realize the information of the whole logistics supply chain. Make logistics more efficient and "smart". The era of "Internet +" has come, and Internet + logistics has also become a new direction of logistics development, which can better adapt to the development of "One Belt And One Road". "Internet +" plan of action, with countries to build perfect, transparent, open logistics information platform, take advantage of the Internet to achieve management monitoring, operation, financial payment operation of information sharing, to promote the whole logistics supply chain information. Government efforts to the construction of Jilin province transportation information network and various provinces and cities and counties of freight hub station connected to the Internet, to achieve with the entire northeast China and even the entire national logistics center to realize information sharing. Established based logistics statistical database, solid research in Jilin area big data system construction of modern logistics by using advanced technology such as the Internet of things, establish visual, perceived and adjustable intelligent system of big data.

Strengthen the cultivation of modern logistics talents. The government should combine the training methods of education and on-the-job training to shape practical talents. Based on the regional industry development, Jilin province, technology upgrades and key project construction, layout, reasonable planning and development to cultivate innovative team, constructing university-enterprise cooperation platform, form the government departments as the guide, with enterprises as the main body, mutual combination of technology innovation mechanism, strengthen development of talent in the area of Jilin province, cultivate more talents and technical backbone, continuously optimize talents entrepreneurship environment, improve the talent security system.

Continuous improvement of infrastructure. In terms of infrastructure construction, we will focus on building logistics infrastructure, logistics parks and industrial parks. Comprehensively promote Jilin industry area construction, and promote the automobile, petrochemical, the integration between modern agriculture and other industries, to speed up the formation of Jilin province economic circle, increase support of Changchun and Jilin city hinterland [4]. Advance in Changchun, northeast Asia international logistics industry garden area railroad terminal construction, improve the Hunchun to Russia card railway transport capacity and northeast Asia railway depot change ability, improve with Russia, the corresponding port of cohesion and coordination, improve port facilities condition, ensure smooth two-way logistics port. Changchun airport expansion and Yanji, the new airport construction project to accelerate the planning airport bonded logistics center, express regulation and other logistics facilities construction, further enhance the Changchun airport in northeast Asia main airport.

Perfect safeguard measures. We should pay attention to the top-level design, guide the outsourcing of non-core business of large enterprises, and promote the development of logistics and 
supply chain industry. We should improve the policy environment, optimize the policy system, and strengthen the policy guarantee and incentive mechanism. Strive to build a fair and reasonable market regulation mechanism, help related industries through the logistics, cash flow, information flow, using relevant policies to promote the innovation in the manufacturing industry and the integration of modern logistics industry innovation, technology innovation and the integration of modern logistics industry, financial innovation and the integration of modern service industry.

Strengthen the construction of industrial chain. To strengthen the construction of the standardization of modern logistics industry in Jilin province to improve the logistics infrastructure, management system, management level, personnel quality, perfect the standard, and improve efficiency has very important significance. With grade a logistics enterprise and national logistics demonstration park to declare for platform, promote the construction of logistics industry technical standard system, promote the transformation from traditional storage and transportation to modern logistics supply chain management[5]. Supply chain management and supply chain service was the core to coordinate the standardization construction, so that the supply chain thought can promote the standard development of modern logistics industry.

Jilin province joint to other countries, continuously improve the logistics environment of the countries along the Silk Road, promote the development of commercial trade and prosperity, building to form a unified large international logistics market.

\section{Acknowledgements}

Social science research project of 12th Five-Year, Jilin Provincial Department of Education (Grant No. 2015573)

Changchun finance and Economics Institute's research team innovation project (Grant No. KYTD201701)

\section{References}

[1] Liu W. Scientific understanding of the Belt and Road Initiative of China and related research themes[J]. Progress in Geography, 2015, 34(5).

[2]Lingjie Kong. The Belt and Road Initiative and China's Foreign Policy Toward Its Territorial and Boundary Disputes[J]. China Quarterly of International Strategic Studies, 2015, 1(02):325-345.

[3] Pang, Rui Qiu, et al.Developmental Strategies of Changchun-Jilin-Tumenjiang of Regional Industry on the Background of Integration[J]. Journal of Northeast Normal University, 2011.

[4] Gao Y, Pang R, Wei X, et al. Research on developmental strategies for regional industry of Changchun-Jilin -Tumenjiang development and open zone[C]// International Conference on Multimedia Technology. IEEE, 2011:4051-4055.

[5] Liu G B. Research on County Economy of Jilin Province in the Background of Changchun-Jilin-Tumenjiang Development[J]. Northeast Asia Forum, 2010. 